\title{
PARTISIPASI MASYARAKAT DALAM PENGELOLAAN OBJEK WISATA ALAM PANTAI KARSUT DI DESA KAMPALA KECAMATAN ARUNGKEKE KABUPATEN JENEPONTO
}

\author{
Riskayana ${ }^{1}$, Abdul Kadir Adys' ${ }^{2}$ Ahmad Taufik ${ }^{1}$ \\ ${ }^{1}$ Fakultas Ilmu Sosial dan Ilmu Politik Universitas Muhammadiyah Makassar \\ Jl. Sultan Alauddin No. 259 Makassar 90221 \\ Telp. 0411 - 866972 ext. 107 Fax. 0411 - 865588 \\ riskayana@gmail.com ahmadtaufik@gmail.com \\ 2Program Studi Ilmu Administrasi Negara Fakultas Ilmu Sosial dan Ilmu Politik \\ Universitas Muhammadiyah Makassar \\ Jl. Sultan Alauddin No. 259 Makassar 90221 \\ Telp. 0411-866972 ext.107.Fax.0411-8655888 \\ abdulkadiradys@gmail.com
}

\begin{abstract}
The purpose of this study to determine community participation in the management of natural attractions in beach Karsut Jeneponto. This research is a qualitative research. Data collection techniques used were observation, interviews, and documentation. The results showed that the participation of society in the form of participation in management planning, charitable giving in the form of ideas / opinions as well as power and responsibility. Kampala village community participation that has begun to diminish. The factors that inhibit the Object Management Karsut Nature Coast is still a lack of funds obtained to repair any damaged facility in Turkish Karsut and still lack infrastructure facilities owned so it is still inadequate.
\end{abstract}

Keywords : community participation, management, tourism

\section{ABSTRAK}

Tujuan penelitian ini untuk mengetahui partisipasi masyarakat dalam pengelolaan objek wisata alam Pantai Karsut di Kabupaten Jeneponto. Jenis penelitian ini adalah penelitian kualitatif. Teknik pengumpulan data yang digunakan yaitu observasi, wawancara, dan dokumentasi. Hasil penelitian menunjukkan bahwa partisipasi masyarakat berupa keikutsertaan dalam perencanaan pengelolaan, pemberian sumbangan berupa ide/pendapat serta tenaga dan juga tanggungjawab. Keikutsertaan masyarakat Desa Kampala yang sudah mulai berkurang. Adapun faktor-faktor yang menghambat dalam Pengelolaan Objek Wisata Alam Pantai Karsut yaitu masih kurangnya dana yang diperoleh untuk memperbaiki setiap fasilitas yang rusak di Pantai Karsut dan masih minimnya fasilitas sarana dan prasarana yang dimiliki sehingga masih kurang memadai.

Kata Kunci: partisipasi masyarakat, pengelolaan, pariwisata 


\section{A. PENDAHULUAN}

Pariwisata merupakan sumber daya alam yang tidak akan pernah habis. oleh karena itu sektor pariwisata harus dirawat dan dijaga keberadaannya. Dan sektor pariwisata juga merupakan salah satu penyumbang pendapatan bagi masyarakat yang tinggal di sekitarnya. Memasuki abad sekarang perhatian terhadap pariwisata sudah sangat meluas, hal ini terjadi karena pariwisata mendatangkan manfaat dan keuntungan bagi masyarakat setempat yang menerima kedatangan wisatawan (tourist reseiving countries).

Perkembangan dunia pariwisata telah mengalami berbagai perubahan baik perubahan pola, bentuk dan sifat kegiatan, serta dorongan orang untuk melakukan perjalanan, cara berfikir maupun sifat perkembangan itu sendiri. Indonesia sebagai negara kepulauan memiliki kekayaan alam yang melimpah tidak terkecuali di Kabupaten Jeneponto, yang memiliki potensi alam yang tentunya dapat dimanfaatkan dalam bidang kepariwisataan sebagai sektor komoditi yang sangat baik bagi perekonomian masyarakat.

Indonesia merupakan negara bahari dengan luas 7,7 juta $\mathrm{km}^{2}$ yang terbagi atas kawasan berupa lautan $75 \%$ (5,8 juta $\left.\mathrm{km}^{2}\right)$ yang berupa dataran yang terdiri dari 17.508 buah pulau yang terdiri atas pulau-pulau besar maupun kecil. Indonesia dikenal sebagai negara dengan kekayaan keanekaragaman hayati (biodiversity) lautan terbesar didunia karena memiliki ekosistem-ekosistem pesisir seperti hutan mangrove, dan padang lamun yang sangat luas dan beragam. Sumberdaya ikan diperkirakan terdapat kurang lebih 7.000 jenis ikan terkandung dalam perairan pesisir dan dalam Indonesia. Indonesia juga memiliki panjang garis pantai $81.000 \mathrm{~km}$ dengan berbagai potensi. Jika melihat kekayaan pesisir pantai tersebut, maka kawasan pesisir berpotensi untuk dikembangkan menjadi daerah tujuan wisata (DTW), antaranya yaitu wisata pantai.

Partisipasi masyarakat dalam pembangunan ataupun pengelolaan pariwisata bukan hanya berarti pengarahan tenaga kerja masyarakat secara sukarela, akan tetapi justru yang lebih penting adalah tergeraknya masyarakat untuk mau memanfaatkan kesempatan-kesempatan mau memperbaikki kualitas hidupnya. Partisipasi berarti peran serta dalam proses pengelolaan objek wisata baik dalam bentuk kegiatan, serta ikut memanfaatkan objek wisata yang dapat dinikmati oleh masyarakat. Pelaku partisipasi sangat tergantung pada besar dan mutu peran sertanya dalam proses pembangunan tergantung tingkat kemampuan serta kesempatannya untuk berpartisipasi dalam proses pembangunan pariwisata tersebut.

$$
\text { Menurut }
$$

Undang-Undang

No.10/2009 Tentang Kepariwisataan dalam sebuah pengelolaan pariwisata perlu direncanakan secara matang dengan memperhatikan segala aspek yang saling mempengaruhi agar tidak terjadi kesalahan yang akan berakibat pada objek wisata tersebut. Apalagi objek wisata tersebut memiliki nilai jual yang sangat berharga baik dari sejarahnya atau pun karena jumlahnya yang terbatas di dunia ini. Hal tersebut dapat dimulai dari potensi yang dimiliki suatu wilayah, adat istiadat, perkembangan ekonomi, sampai aspek politik.

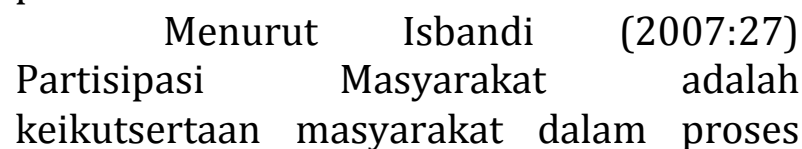
pengidentifikasian masalah dan potensi yang ada di masyarakat, pemilihan dan pengambilan keputusan tentang alternatif solusi untuk menangani masalah, pelaksanaan upaya mengatasi masalah dan keterlibatan masyarakat dalam proses pengevaluasi perubahan yang terjadi. Partisipasi masyarakat dalam pelaksanaan dapat diukur secara nyata dalam aktivitas riil yang merupakan perwujudan program yang telah digariskan didalam kegiatan fisik. Dengan demikian ukurannya adalah bagaimana masyarakat memberikan sumbangan dalam hubungannya dengan kegiatan. Sumbangan tersebut dapat berupa uang, material (barang) dan juga tenaga. 
Dan sumbangan tersebut tidak tertutup kemungkinan dapat dilakukan secara ketigatiganya.

Tujuan dari partisipasi masyarakat untuk menghasilkan ide dan persepsi yang berguna untuk masyarakat yang berkepentingan (public interest) dalam rangka meningkatkan kualitas pengambilan keputusan (Santoso, 1990) sebab dengan melibatkan masyarakat yang potensial terkena dampak dari kegiatan dari cara mengambil keputusan, kebutuhan dari pengaharapan kelompok masyarakat, dan kelompok masyarakat itu menuangkannya dalam suatu konsep. Reaksi dari pandangan masyarakat saja akan membantu masyarakat itu sendiri dalam hal pengambilan keputusan untuk menentukan prioritas, arah dan kepentingan yang positif dari berbagai faktor.

Pantai karsut ini awalnya adalah sebuah tempat pemancingan milik pribadi Andi Tahal Fasni Karaeng Sutte. Karena lokasinya yang berdekatan dengan pantai dan melihat banyaknya orang yang datang kesana maka masyarakat desa Kampala berinisiatif memberikan ide/gagasan maupun saran kepada pemilik tempat untuk menjadikan pantai itu sebagai objek wisata. Setelah tempat pemancingan milik Andi Tahal Fasni Karaeng Sutte beralih menjadi sebuah tempat objek wisata maka partisipasi masyarakat sudah mulai berkurang terlihat dari sudah tidak adanya lagi masyarakat di Desa Kampala yang ingin ikut berpartisipasi dalam pengelolaan objek wisata alam pantai karsut, mulai dari pemberian tenaga maupun sumbangan materi. Padahal awalnya masyarakatlah yang pertama kali mengusulkan untuk menjadikan tempat pemancingan tersebut sebagai objek wisata. Hal itu dikarenakan tidak sesuainya antara tujuan dengan harapan masyarakat lagi sehingga pengelolaan objek wisata pantai karsut sudah kurang optimal lagi.

Jika dilihat objek wisata yang ada di pantai karsut memiliki nilai jual yang sangat tinggi dan dapat menarik minat para wisatawan lokal maupun wisatawan asing. Dan juga dapat membuka peluang bisnis bagi warga setempat yang tinggal di sekitar pantai karsut. Sehingga mampu meningkatkan perekonomian bagi masyarakat Desa Kampala.

Berdasarkan uraian diatas, maka penulis tertarik melakukan penelitian mengenai "Partisipasi Masyarakat Dalam
Pengelolaan Obyek Wisata Alam Pantai Karsut Di Desa Kampala Kecamatan Arungkeke Kabupaten Jeneponto.dan faktor yang menghambat dalam pengelolaan objek wisata alam pantai karsut di Desa Kamapala Kecamatan Arungkeke Kabupaten Jeneponto".

Tujuan yang ingin dicapai dalam pelaksanaan ini adalah mengetahui partitisipasi masyarakat dalam pengelolaan objek wisata alam pantai karsut di Desa Kampala Kecamatan Arungkeke Kabupaten Jeneponto dan faktor penghambat dalam pengelolaan objek wisata alam pantai karsut di Desa Kampala Kecamatan Arungkeke Kabupaten Jeneponto.

\section{B. KONSEP PARTISIPASI MARSYARAKAT}

$$
\text { Rahardjo dalam Mardijono }
$$

(2008:19) mengemukakan partisipasi diartikan sebagai upaya peran serta masyarakat dalam suatu kegiatan baik dalam bentuk pernyataan maupun kegiatan. Lebih lanjut dijelaskan partisipasi merupakan keikutsertaan masyarakat dalam program-program pembangunan. Pada dasarnya partisipasi dibedakan menjadi dua, yaitu partisipasi yang bersifat swakarsa dan partisipasi yang bersifat simobilisasikan. Partisipasi swakarsa mengandung arti bahwa keikutsertaan dan peran sertanya atas dasar kesadaran dan kemauan sendiri, sementara partisipasi yang dimobilisasikan memiliki arti keikutsertaan dan berperan serta atas dasar pengaruh orang lain.

Keikutsertaan dan keterlibatan masyarakat mutlak harus dilakukan dalam partisipasi dan bukan hanya keterlibatan mental semata, tetapi harus disertai dengan keterlibatan mulai dari perencanaan sampai pelaksanaan. Satropoetro dalam Apriyani (2012:34), mengemukakan ada tiga buah unsur penting yang harus diperhatikan dalam melaksanakan partisipasi, yaitu : Bahwa partisipasi, keikutsertaan, keterlibatan atau peranserta, sesungguhnya merupakan suatu keterlibatan mental dan perasaan, lebih dari semata-mata atau hanya keterlibatan secara jasmani. Unsur kedua adalah kesediaan memberi sesuatu sumbangan kepada usaha untuk mencapai tujuan 
kelompok. Ini berarti, bahwa terdapat rasa kesukarelaan untuk membantu kelompok. Seseorang menjadi anggota dengan segala nilainya. Unsur ketiga adalah unsur tanggungjawab. Unsur tersebut merupakan segi yang menonjol dari rasa menjadi anggota. Diakui sebagai anggota artinya ada rasa (sense of belongingnes).

Partisipasi

masyarakat dapat simpulkan sebagai pembentukan kerja sama yang berdasarkan pada kepercayaan dan keterbukaan. Menutut Habitat partisipasi masyarakat bukanlah untuk ; Menyuruh masyarakat untuk melakukan pekerjaan pada proyek-proyek pemerintah yang berkaitan dengan pengembangan masyarakat, Menanyakan pendapat masyarakat tentang program yang telah dipersiapkan, untuk selanjutnya membuat perubahan-perubahan kecil dan meminta masyarakat untuk membayar sebagaian biaya proyek atau kegiatan yang dilakukan.

Menurut Isbandi (2007:27) Partisipasi Masyarakat adalah keikutsertaan masyarakat dalam proses pengidentifikasian masalah dan potensi yang ada di masyarakat, pemilihan dan pengambilan keputusan tentang alternatif solusi untuk menangani masalah, pelaksanaan upaya mengatasi masalah dan keterlibatan masyarakat dalam proses pengevaluasi perubahan yang terjadi.

\section{KONSEP PENGELOLAAN PARIWISATA}

Pengertian pengelolaan dalam kamus umum bahasa Indonesia memberikan penjelasan sebagai berikut : (1) proses, cara pembuatan mengelola, (2) proses melakukan perbuatan tertentu dengan menggerakan tenaga orang lain, (3) proses yang membentuk merumuskan kebijakan dan tujuan organisasi, dan (4) proses yang memberikan pengawasan pada semua hal yang terlibat dalam pelaksanaan kebijakan dan pencapaian tujuan. (5) Manajemen adalah suatu proses yang membedakan atau perencanaan, pengorganisasian, pelaksanaan dan pengawasaan, dengan memanfaatkan baik ilmu maupun seni agar dapat mencapai tujuan yang telah ditetapkan sebelumnya. Pengertian diatas dapat disimpulkan bahwa pengertian pengelolaan adalah suatu proses kegiatan yang meliputi perencanaan, pengorganisasian, pelaksanaan, dan pengawasaan. Perencanaan adalah suatu pemiliharaan yang berhubungan dengan waktu yang akan datang dalam menggambarkan dan merumuskan kegiatan-kegiatan yang diusulkan demi mencapai hasil yang dikehendaki.

(Organizing)

Pengorganisasian adalah penentuan, pengelompokan, dan pegaturan berbagai kegiatan yang dianggap perlu untuk mencapai tujuan. Pelaksanaan (Acuntting) Pelaksanaan adalah usaha agar setiap anggota kelompok mengusahakan pencapaian tujuan dengan berpedoman dengan pada perencanaan dan usaha pengorganisasian.

Pengawasan

(Controlling) pengawasan adalah proses penentuan apa yang seharusnya diselesaikan yaitu penilaian, pelaksanaan, bila perlu melakukan tindakan korektif agar pelaksanaannya tetap sesuai dengan rencana.

Pariwisata secara etimologi berasal dari bahasa sangsekerta yang terdiri dari dua kata yaitu "Pari" dan "Wisata". Pari berarti berulang-ulang, berkali-kali atau berputar-putar, sedangkan wisata berartiperjalanan atau bepergian, jadi pariwisata berarti perjalanan yang dilakukan secara beputar-putar, berulangulang atau berkali-kali. Pariwisata adalah suatu perjalanan yang dilakukan untuk sementara waktu, yang diselenggarakan dari tempat lain dengan maksud bukan untuk berusaha (business) atau mencari nafka ditempat yang dikunjungi, tetapi semata-mata untuk menikmati perjalanan tersebut guna bertamasyah dan rekreasi untuk memenuhi keinginan yang beraneka ragam.

Undang-undang Nomor 10 Tahun 2009 tentang kepariwisataan, pariwisata adalah berbagai macam kegiatan wisata dan didukung berbagai fasilitas serta layanan yang disediakan oleh masyarakat, pengusaha, pemerintah, dan pemerintah daerah. Pariwisata adalah suatau kegiataan kemanusian berupa hubungan anatara orang baik dari negara yang sama antarnegara atau hanya dari daerah lain atau negara lain atau benua lain untuk memenuhi berbagai kebutuhan kecuali kegiatan untuk memperoleh penghasilan, meskipun pada perkembangan selanjutnnya batasan "memperoleh penghasilan" masih kabur. 


\section{METODE PENELITIAN}

Lokasi penelitian ini dilaksanakan di Desa Kampala Kecamatan Arungkeke Kabupaten Jeneponto. Jenis penelitian ini yaitu kualitatif, observasi, dokumentasi dan pengumpulan data. sehingga tujuan penelitian ini adalah menggambarkan tentang partisipasi masyarakat dalam pengelolaan objek wisata alam Pantai Karsut di Desa Kecamatan Arungkeke Kabupaten Jeneponto dan realita empirik dibalik fenomena secara terperinci, mendalam dan tuntai. Tipe penelitian yang digunakan dalam penelitian ini adalah deskriptif kualitatif, Data primer merupakan data yang dapat diperoleh langsung dari lapangan, atau tempat penelitian. Sumber data utama dari penelitian kualitatif adalah katakata dan tindakan merupakan sumber data yang diperoleh dari lapangan dengan cara mengamati dan mewawancarai.

Peneliti akan mengolah dan menganalisis data dengan menggunakan metode deskriptif kualitatif yang merupakan suatu teknik yang menggambarkan dan menginterprestasikan arti data-data yang telah terkumpul dengan memberikan perhatian dan merekam sebanyak mungkin aspek situasi yang diteliti saat itu, sehingga memperoleh gambaran secara umum dan menyeluruh tentang keadaan yang sebenarnya. Tujuan deskriptif ini adalah membuat deskripsi, gambaran, atau lukisan secara sistematis, faktual dan terpercaya, serta akurat terhadap fakta-fakta, sifat-sifat, serta hubungan antara fenomena yang diselidiki. Tringulasi terbagi atas 3 (tiga) yaitu: triangulasi sumber. triangulasi waktu dan triangulasi metode.

\section{E. HASIL DAN PEMBAHASAN}

Perncanaan merupakan proses yang mempersiapkan seperangkat keputusan untuk melakukan tindakan dimasa depan. Tahap perencanaan merupakan tahapan awal dalam proses pelaksanaan pengelolaan objek wisata. Hal ini dimaksudkan bahwa perencanaan akan memberikan arah, langkah atau pedoman dalam proses pembangunan pengelolaan objek wisata. Pada tahapan ini akan ditelusuri aktivitas atau kegiatan yang dilakukan oleh masyarakat, dimulai dari keterlibatan mereka dalam rencana program pembangunan objek wisata.

\section{Peralihan dari tempat pemancingan menjadi objek wisata}

Pariwisata merupakan sumber daya alam yang tidak akan pernah habis. oleh karena itu sektor pariwisata harus dirawat dan dijaga keberadaannya. Objek wisata adalah suatu bentukan dan fasilitas yang berhubungan yang dapat menarik minat wisatawan atau pengunjung untuk datang ke suatu daerah atau tempat tertentu. Objek dan daya tarik wisata merupakan dasar bagi kepariwisataan. Tanpa adanya daya tarik di suatu daerah atau tempat tertentu, kepariwisataan sulit untuk dikembangakan. Berdasarkan hasil wawancara langsung yang penulis lakukan dengan beberapa informan yang ada terkait dengan peralihan tempat pemancingan menjadi suatu objek wisata, maka diperoleh berbagai informasi atas wawancara yang penulis lakukan sebagai berikut:

Sebagaimana wawancara yang di lakukan penulis dengan pengurus pantai karsut yang mengatakan bahwa :

"Awalnya pantai karsut ini adalah merupakan milik pribadi Dr. A.Tahal Fasni karaeng Sutte yang dijadikan sebagai tempat untuk memancing dan juga beristirahat bersama keluarga. Karena lokasi ini berdekatan dengan pantai dan banyaknya orang yang datang kepantai karsut maka timbulah ide Dr. A.Tahal Fasni karaeng sutte di dukung oleh warga setempat untuk menjadikan pantai karsut sebagai objek wisata alam dan kemudian di bangunlah berbagai fasilitas di pantai karsut ini mulai dari tempat pemancingan, kolam renang, baruga dan balai-balai untuk tempat peristirahatan pengunjung sehabis berenang". (wawancara, JA).

Berdasarkan hasil wawancara di atas dapat diperoleh jawaban bahwa perencanaan peralihan suatu tempat pemancingan yang diusulkan oleh masyarakat Desa Kampala untuk menjadikanya sebagai sebuah objek wisata yang memiliki daya tarik sehingga mampu menjadikan suatu tempat pemancingan 


\section{Vol. II No. 2 Oktober 2012}

menjadi suatu objek wisata yang memiliki nilai jual tinggi yang mampu menarik minat para wisatawan/ pengunjung untuk datang berwisata.

Sebagaimana wawancara yang di lakukan penulis dengan penjaga pantai karsut yang mengatakan bahwa :

"Mengapa pantai karsut ini di jadikan sebagai objek wisata alam karena melihat banyaknya orang yang berkunjung datang kemari. Maka timbullah ide/gagasan warga berserta pemilik pantai bapak Dr.A.Tahal Fasni Karaeng Sutte untuk menjadikan pantai karsut itu sebagai objek wisata alam tak kurang Rp450 juta dihabiskan untuk pembangunan kawasan wisata pantai karsut tersebut."( wawancara, BJ).

Berdasarkan hasil wawancara di atas dapat diperoleh jawaban bahwa Suatu objek wisata yang memiliki daya tarik mampu menjadikan suatu tempat pemancingan menjadi suatu objek wisata yang memiliki nilai jual tinggi yang mampu menarik minat para wisatawan/ pengunjung untuk datang berwisata ke pantai karsut. Oleh karenanya pemilik tempat pemancingan yaitu Andi Tahal Fasni Karaen Sutte bersedia mengeluarkan dana pribadinya sebesar 450 juta untuk pengelolaan objek wisata alam pantai karsut. Serta masyarakat Desa Kampala Juga bersediah ikut ambil bagian dalam berpartisipasi memberikan sumbangan berupa tenaganya untuk ikut mendirikan baruga dan juga villa.

\section{Pengelolaan Objek Wisata}

Pengelolaan obyek wisata adalah mengembangkan potensi alam yang dimiliki oleh suatu daerah melalui pariwisata yang memiliki nilai jual yang tinggi sehingga mampu bersaing dengan daerah lain. Melalui pengelolaan objek wisata yang baik dengan penyediaan fasilitas sarana dan prasarana mampu meningkatkan kualitas objek wisata sehingga mampu menarik minat wisatawan/pengunjung untuk datang.

Sebagaimana wawancara yang di lakukan penulis dengan pemilik pantai yang mengatakan bahwa:

"Dalam pengelolaan objek wisata ini, sudah kurang optimal lagi karena masyarakat desa Kampala tidak mau lagi ikut berpartisipasi. Padahal mereka sendiri yang mengusulkan kepada pemilik tempat pemancingan untuk menjadikan tempat pemancingannya sebagai objek wisata". (wawancara, KS).

Berdasarkan hasil wawancara di atas dapat diperoleh jawaban bahwa dalam pengelolaan objek wisata tanpa ada partisipasi dari masyarakat pengelolaan objek wisata alam pantai karsut akan kurang optimal jika dilihat pantai karsut memiliki nilai jual yang tinggi sehingga mampu bersaing dengan daerah lain. Melalui pengelolaan objek wisata yang baik dengan penyediaan fasilitas sarana dan prasarana mampu meningkatkan kualitas objek wisata sehingga mampu menarik minat wisatawan/pengunjung untuk datang ke pantai karsut. Sebagaimana wawancara yang di lakukan penulis dengan Wakil Ketua Pokdarwis Singa'ken yang mengatakan bahwa:

"Pengelolaan objek wisata sudah kurang optimal karena masyarakat desa Kampala tidak mau lagi ikut berpartisipasi karena apa yang mereka inginkan tidak sesuai dengan harapannya" (wawancara, $S A)$.

Berdasarkan hasil wawancara di atas maka diperoleh jawaban bahwa proses partisipasi masyarakat dalam mengelola pantai karsut adalah tidak luput dari yang namanya keterlibatan masyarakat untuk mau ikut berpasrtisipasi dalam pengelolaan objek wisata alam pantai karsut.

\section{Sumbangan}

Keikutsertaan dan keterlibatan masyarakat mutlak harus dilakukan dalam partisipasi dan bukan hanya keterlibatan mental semata, tetapi harus disertai dengan keterlibatan mulai dari perencanaan sampai pelaksanaan. Satropoetro dalam Apriyani (2012:34) Unsur kedua dari indikator partisipasi masyarakat adalah 
kesediaan untuk memberi sesuatu sumbangan kepada keberhasilah objek wisata untuk mencapai tujuan kelompok yang dibentuk agar mampu mengelolaa objek wisata menjadi lebih baik dan berkembang. Ini berarti bahwa terdapat rasa kesukarelaan untuk membantu kelompok agar ingin berpartisipasi membantu proses perencanaan dan pelaksanaan pengelolaan objek wisata.

\section{Pemberian Ide/Gagasan}

Pemberian sumbangan ide/gagasan yang diberikan masyarakat setempat terhadap pemilik tempat pemancingan agar mau menjadikannya sebagai tempat objek wisata yang memiliki nilai jual yang sangat tinggi. Menurut mereka akan mampu meningkatkan perekonomian mereka dengan membuka peluang bisnis di sekitar lokasi pantai karsut.

Sebagaimana wawancara yang di lakukan penulis dengan Kepala Desa Kampala yang mengatakan bahwa:

"Masyarakat yang pertama kali memiliki inisiatif untuk menjadikan tempat pemancingan tersebut sebagai tempat objek wisata. Akan tetapi setelah usulan yang mereka sampaikan dan pengelolaan objek wisata pantai karsut berjalan, tiba-tiba masyarakat tidak mau lagi ikut berpartisipasi karena mereka menganggap apa yang mereka harapkan tidak sesuai dengan keinginanya". (wawancara ,KK)

Berdasarkan hasil wawancara di atas dapat diperoleh jawaban bahwa dalam pelaksanaan pengelolaan objek wisata alam pantai karsut, peranan masyarakat sangat diperlukan dalam ikut berpartisipasi. Mulai dari segi keikutsertaannya memberikan dukungan, ide/pendapat, bahkan sampai pada pemberian tenaga. Akan mampu menunjang optimalnya pengelolaan pantai karsut.

Sebagaimana wawancara yang di lakukan penulis dengan anggota kelompok pokdarwis singaken yang mengatakanbahwa:

"Masyarakat sangat senang ketika usulan ide/gagasan mereka diterima dengan pemilik tempat pemancingan agar mau menjadikan tempat pemancingannya sebagai objek wisata sehingga membantu perekonomian mereka. Setelah pemilik pantai mengelola pantai tersebut tiba-tiba masyarakat tidak mau lagi ikut berpartisipasi dalam pengelolaan pantai karsut. Dikarenakan tidak sesuainya antara tujan dengan harapan mereka". (wawancara, MI)

Berdasarkan hasil wawancara di atas maka diperoleh jawaban bahwa proses partisipasi masyarakat dalam mengelola pantai karsut adalah tidak luput dari yang namanya keterlibatan masyarakat untuk mau ikut berpasrtisipasi dalam pengelolaan objek wisata alam pantai karsut.

\section{Pemberian Tenaga}

Partisipasi masyarakat dalam tahap pengelolaan objek wisata alam pantai karsut merupakan sebagai sumbangan masyarakat dalam bentuk pemberian tenaga kerja yang diberikannya. Sebagaimana wawancara yang di lakukan penulis dengan pemilik pantai karsut yang mengatakan bahwa:

"Masyarakat desa Kampala sudah tidak mau lagi memberikan sumbangsi dalam hal pemberian tenaga mereka sudah acuh tak acuh lagi". (wawancara,KS)

Berdasarkan hasil wawancara di atas dapat diperoleh jawaban bahwa partisipasi masyarakat dalam tahap pengelolaan objek wisata alam pantai karsut merupakan sebagai sumbangan masyarakat dalam bentuk pemberian tenaga kerja yang diberikannya. Sebagaimana wawancara yang di lakukan penulis dengan penjaga pantai karsut yang mengatakan bahwa :

"Setiap jejeran baruga yang ada dipantai karsut awalnya semua masyarakat setempat yang membangunnya secara sukarela. Akan tetapi baruga yang berjejeran sudah banyak yang rusak ketika masyarakat setempat di minta tenaganya mereka sudah tidak mau lagi."( wawancara, MR) 


\section{Vol. II No. 2 Oktober 2012}

Berdasarkan hasil wawancara di atas dapat diperoleh jawaban bahwa akibat partisipasi yang kurang lagi masyarakat berikan maka banyak fasilitas di pantai karsut mengalami kerusakan. Di akibatkan tidak sesuainya antara tujuan dan harapan masyarakat Desa Kapala yaitu dengan adanya objek wisata ini mampu membuka peluang bisnis bagi masyarakat Desa Kampala agar perekonomian mereka dapat meningkat.

\section{Tanggungjawab}

Unsur ketiga dari partisipasi masyarakat tersebut unsur tanggungjawab yang merupakan bentuk partisipasi masyarakat dalam pengelolaan obyek wisata ditentukan oleh sampai dimana tingkat partisipasi masyarakat dalam keikutsertaan dan keterlibatan masyarakat mulai dari perencanaan sampai dengan proses pelaksanaan.

Pemeliharaan kebersihan objek wisata perlu diperhatikan demi kenyamanan para wisatawan/pengunjung saat berwisata. Menjaga kebersihan Pantai Karsut akan memberikan kenyamanan bagi pengunjung.

Sebagaimana wawancara yang di lakukan penulis denganpenjaga pantai yang mengatakan bahwa:

"Salah satu kendala yang ada dipantai karsut adalah banyaknya daun-daun kering yang berjatuhan didalam pantai. Pemiliharaan kebersihan pantai hanya dilakukan seminggu sekali saja. (wawancara, BJ).

Berdasarkan hasil wawancara di atas dapat diperoleh jawaban bahwa menjaga kebersihan pantai karsut sangat perlu diperhatikan demi kenyamanan pengunjung Suasana semakin nyaman terasa, ketika angin berembus dari sela-sela pohon kelapa yang berderet rapi di bibir pantai. Sehingga membuat para wisatawan akan senang berkunjung kepantai karsut.

Sebagaimana wawancara yang di lakukan penulis dengan pemilik pantai karsut yang mengatakan bahwa:

"Pemilliharaan kebersihan pantai sudah kurang terjaga dikarenakan kurangnya pengurus pantai yang bersediah membantu menjaga memelihara kebersihan pantai. Saya harus mengeluarkan uang pribadi saya untuk membayar orang agar menjaga dan memelihara kebersihan pantai karsut". (wawancara, KS)

Berdasarkan hasil wawancara di atas dapat diperoleh jawaban bahwa pemiliharaan kebersihan objek wisata perlu diperhatikan demi kenyamanan para wisatawan/pengunjung saat berwisata. Menjaga kebersihan Pantai Karsut akan memberikan kenyamanan bagi pengunjung yang datang ke pantai karsut. Pemeliharaan keamanan juga harus diperhatikan mulai dari keamanan fasilitas sarana dan prasarana maupun juga keamanan bagi para pengunjung saat berada dipantai karsut. Sebagaimana wawancara yang di lakukan penulis dengan pengurus pantai karsut yang mengatakan bahwa:

"Mengenai soal keamanan fasilitas sarana dan prasarana yang ada dipantai karsut masih minim sekali karena fasilitas yang tersedia sangat kurang seperti pelampung dan juga penjaga pantai yang berada disekitar pinggir pantai".(wawancara, JA)

Hal senada juga disampaikan oleh pengurus pantai karsut yang mengatakan bahwa:

"Melihat fasilitas yang ada dipantai karsut sudah banyak yang rusak karena tidak adanya penjaga pantai yang tinggal mengawasi setiap fasilitas yang ada di dalam sehingga anak-anak yang tinggal disekitaran pantai tidak ada yang mengawasi saat bermain mengunakan fasiltas yang ada di pantai karsut." (wawancara, MR).

Berdasarkan hasil wawancara di atas dapat diperoleh jawaban bahwa peningkatan keamanan sangat perlu dilakukan demi menjaga rasa keamanan bagi para pengunjung saat berada dipantai karsut.

Pengelolaan keuangan yang dimaksudkan adalah setiap uang yang diperoleh baik dari pemilik pantai, masyarakat maupun pengunjung agar mampu terkelola dengan baik maka harus 
ada semacam kelompok/organisasi yang mengelola keuangan yang masuk dipantai karsut maka dibuatlah kelompok sadar wisata alam atau Pokdarwis yang diberi nama singaken kelompok inilah yang bertanggungjawa mengurus dan mengelola keuangan pantai karsut.

Sebagaimana wawancara yang di lakukan penulis kepada salah satu informan yaitu MI selaku anggota Pokdarwis Singaken yang mengatakan bahwa:

"Kelompok sadar wisata alam (Pokdarwis) yang diberi nama singaken inilah yang mengelola semua keuangan yang masuk dipantai karsut. Setiap uang yang terkumpul digunakan untuk menambah fasilitas disarana dan prasarana dipantai karsut serta memperbaiki setiap fasilitas yang rusak dipantai karsut".(wawancara, MI)

Berdasarkan hasil wawancara di atas dapat diperoleh jawaban bahwa tanggungjawab dalam artian ini adalah bukan hanya kelompok pokdarwis yang ikut ambil bagian saja dalam memelihara dan merawat pantai karsut akan tetapi juga mengikut sertakan masyarakat dalam proses dan usaha pengembangan pengelolaan objek wisata, sehingga rasa memiliki dan tanggung jawab tumbuh pada masyarakat terhadap objek wisata yang ada di daerahnya. Dengan rasa memiliki dan tanggungjawab ini, maka masyarakat akan ikut merawat dan memelihara kelestarian objek wisata tersebut.

Sebagaimana wawancara yang di lakukan penulis dengan Kepala Desa Kampala yang mengatakan bahwa:

"Kelompok sadar wisata alam (POKDARWIS) yang diberi nama singaken. Selain kelompok ini di bentuk oleh kepala Desa Kampala yang bertujuan untuk mengelola keuangan pantai karsut, kelompok ini juga bertujuan untuk mengembangkan wisata alam di desa kampala. (wawancara, KK)

Hal senada juga di sampaikan oleh Wakil Ketua Pokdarwis yang mengatakan bahwa:

"Ada semacam kelompok sadar wisata (Pokdarwis) yang diberi nama Singaken yang beranggotakan 15 orang mereka inilah yang membantu mengurus pantai karsut setiap ada dana yang masuk baik itu dari pengunjung, maupun dana dari pemilik pantai itu sendiri Pokdarwislah yang mengelolanya dan mengurus pantai karsut". (wawancara, SI)

Berdasarkan hasil wawancara di atas dapat diperoleh jawaban bahwa partisipasi masyarakat juga dapat diartikan sebagai kerjasama yang bersifat langsung dengan sedemikian rupa sehingga setiap kelompok masyarakat seperti kelompok sadar wisata ataupun masyarakat desa Kampala sendiri dapat terlibat secara langsung dan nyata dalam proses pengelolaan objek wisata alam pantai karsut.

\section{Faktor Penghambat.}

Dana merupakan salah satu unsur utama yang sangat penting dalam menunjang berhasilnya pembangunan suatu pengelolaan objek wisata alam. Meskipun terkadang dana yang diperoleh dari masyarakat dan juga pengunjung sudah ada. Akan tetapi dana itu masih kurang untuk mengelola pantai

Sebagaimana wawancara yang di lakukan penulis dengan pengurus pantai karsut yang mengatakan bahwa:

"Mengenai hal tersebut faktor ataupun kendala yang dihadapi dalam mengelola pantai karsut adalah masih minimnya dana yang diperoleh dari masyarakat dan juga para pengunjung untuk menunjang pembangunan pantai karsut. Masih ada beberapa hal lagi yang harus di benahi di pantai karsut mulai dari akses jalan masuk ke pantai karsut yang masih berbatu-batu sampai pada perbaikan fasilitas yang telah banyak rusak dan harus diganti segera untuk menunjang kualitas sarana dan prasarana objek wisata alam pantai karsut" (wawancara,PP) 
Berdasarkan hasil observasi dan wawancara yang peneliti lakukan dapat disimpulkan bahwa sumbangan yang diberikan oleh masyarakat berikan belum mampu membenahi pantai karsut di karenakan sudah banyaknya fasilitas sarana dan prasarana yang telah rusak.

Sarana dan prasarana merupakan segala jenis peralatan, perlengkapan dan fasilitas lain yang tersedia yang dapat digunakan dalam menikmati wisata pantai. Peranan sarana dan prasarana sangat penting menunjang peningkatan kualitas objek wisata alam pantai karsut sehingga berpengaruh terhadap kenyamanan para pengunjung yang sedang berkunjung. Sedangkan apabila kurangnya sarana dan prasarana yang tersedia akan mengurangi minat para pengunjun/wisatawan untuk berkunjung kesana sehingga akan berpengauh kurangnya pendapatan yang akan diperoleh warga setempat. Sebagaimana hasil wawancara yang dilakukan peneliti dengan pengurus pantai karsut yang mengatakan bahwa:

"Mengenai hal fasilitas sarana dan prasarana yang ada di pantai karsut sudah banyak yang rusak seperti balai, kamar mandi, motor speed dan juga perahu bebek sudah tidak dapat lagi dipergunakan". (wawancara, PP).

Berdasarkan hasil observasi dan wawancara yang peneliti lakukan dapat disimpulkan bahwa sarana dan prasaranan yang ada di objek wisata alam pantai karsut masih kurang memadai dikarenakan banyaknya fasilitas saranan dan prasarana yang sudah rusak dan perlu segera di perbaiki sehingga pengunjung dapat menggunakan kembali fasilitas yang ada.

\section{PENUTUP}

Partisipasi Masyarakat Dalam Pengelolaan Objek Wisata Alam Pantai Karsut Di Kabupaten Jeneponto termasuk dalam kategori lumayan tinggi.Agar partisipasi masyarakat dapat terlaksana maka yang harus nampak dalam pengelolaan objek wisata alam pantai karsut di Desa Kampala Kecamatan Arungkeke Kabupaten Jeneponton adalah kesedian masyarakat setempat untuk ikut berperan serta dalam proses perencanaan dalam peralihan tempat pemancingan menjadi sebuah objek wisata, dan juga dalam pengelolaan objek wisata, partisipasi dalam bentuk sumbangan adalah dapat dilihat dari baruga maupun villa yang ada di pantai karsut semuanya masyarakat setempat yang membangunnya. kemudian ada juga pemberian dukungan, ide/pendapat, dan juga pemberian tenaga. Disamping itu pula adanya kelompok/organisasi yang bertanggungjawab. Ketiga indikator ini belum berjalan maksimal dapat terlihat dari keikutsertaan masyarakat Desa Kampala yang sudah mulai berkurang, dikarenakan apa yang mereka inginkan tidak sesuai dengan harapan mereka yaitu meskipun dengan adanya objek wisata alam pantai karsut ini belum mampu meningkatkan pendapatan masyarakat Desa Kampalaoleh karenanya itu masyarakat Desa Kampala sudah tidak ingin lagi ikut berpartisipasi dalam pengelolaan objek wisata alam pantai karsut.

Faktor-faktor yang menghambat dalam pelaksanaan dalam Pengelolaan Objek Wisata Alam Pantai Karsut Di Desa Kampala Kecamatan Arungkeke Kabupaten Jeneponto adalah: masih kurangnya dana yang diperoleh untuk memperbaiki setiap fasilitas-fasilitas yang rusak di pantai karsut dan masih minimnya fasilitas sarana dan prasarana yang dimiliki sehingga masih kurang memadai. Berkenaan dengan pembahasan dan kesimpulan di atas, maka penulis juga akan memberikan beberapa saran yang dapat memberikan manfaat bagi pemerintah kabupaten jeneponto masyarakat setempat, dan juga penulis.

\section{DAFTAR PUSTAKA}

Apriyani, Rini. 2012. Partisipasi Masyarakat Dalam pelestarian Hutan Mangrove Di Desa Eretan Kulon Kecamatan Kandanghaur Kabupaten Indramayu. Bandung : Universitas Pendidikan Indonesia.

Aziz, Azril. 2003. Kajian Pengembangan Pariwisata Bahari Di Kelurahan Pulau Kelapa Kecamatan Kepulauan Seribu Utara, Kabupaten Administrasi Kepulauan Seribu, Daerah Khusus Ibukota Jakarta. Program Pasca 
Sarjana, Bogor : Institut Pertanian Bogor.

Isbandi Rekminto Adi, 2007. Perencanaan Partisipsi Berbasis Aset Komoditis, dari pemikiran meneuju penerapan. Depok : FISIP UI Press.

Mardijono. 2008. Persepsi dan Partisipasi Nelayan terhadap Pengelolaan kawasan Konservasi Laut Kota Batam. (tesis) Semarang : Universitas Diponegoro.

Santoso, Gempur. 2005. Metedologi Penelitian, Jakarta :Prestasi Pustaka Publisher.

Susanti, Yeni. 2012. Partisipasi Masyarakat Lokal Dalam Pengembangan Objek Wisata Goa Tabuhan Seabagai Daerah Tujuan Wisata (Tourist Destination Area) Di Desa Wareng Kecamatan Punung Kabupaten Pacitan. Surakarta : Universitas Sebelas Maret. 